\title{
Landscaping capacity-building initiatives in epidemiology in India: bridging the demand-supply gap
}

\author{
Sanjay Zodpey ${ }^{l}$, Anuja Pandey ${ }^{1}$, Manoj Murhekar ${ }^{2}$, Anjali Sharma ${ }^{1}$
}

\begin{abstract}
India, the second most populous country in the world, has $17 \%$ of the world's population but its total share of global disease burden is $21 \%$. With epidemiological transition, the challenge of the public health system is to deal with a high burden of noncommunicable diseases, while still continuing the battle against communicable diseases. To combat this progression, public health capacity-building initiatives for the health workforce are necessary to develop essential skills in epidemiology and competencies in other related fields of public health. This study is an effort to systematically explore the training programmes in epidemiology in India and to understand the demand-supply dynamics of epidemiologists in the country. A systematic, predefined approach, with three parallel strategies, was used to collect and assemble the data regarding epidemiology training in India and assess the demand-supply of epidemiologists in the country. The programmes offering training in epidemiology included degree and diploma courses offered by departments of preventive and social medicine/community medicine in medical colleges and 19 long-term academic programmes in epidemiology, with an estimated annual output of 1172 per year. The demand analysis for epidemiologists estimated that there is need for at least 3289 epidemiologists to cater for the demand of various institutions in the country. There is a wide gap in demand-supply of epidemiologists in the country and an urgent need for further strengthening of epidemiology training in India. More capacity-building and training initiatives in epidemiology are therefore urgently required to promote research and address the public health challenges confronting the country.
\end{abstract}

Key words: capacity-building, demand and supply, epidemiologists, epidemiology, India

\section{BACKGROUND}

India, the second most populous country in the world, has $17 \%$ of the world's population but its total share of global disease burden is $21 \% .{ }^{1}$ A large portion of this disproportionately high burden is contributed by preventable communicable diseases. ${ }^{2}$ The dynamics of pathogens, further compounded by factors that favour emergence and fast spread of infectious diseases, demand epidemiological competencies in compilation, assessment and interpretation of data (from various sources of health, meteorological and related areas), making use of the information to initiate appropriate and timely public health measures. ${ }^{3}$ With epidemiological transition, the challenge of the public health system is to deal with a high burden of noncommunicable diseases, while still continuing the battle against communicable diseases. Challenges in disease control
${ }^{1}$ Public Health Foundation of India, New Delhi, India, ${ }^{2}$ National Institute of Epidemiology, Indian Council of Medical Research, Chennai, India

Address for correspondence: Dr Anuja Pandey, Assistant Professor, Public Health Foundation of India Institutional Area, Vasant Kunj, New Delhi - 110 070, India Email: anuja_2kn@yahoo.com 
Epidemiology provides a sound and rational foundation for public health professionals to develop public policies and make meaningful decisions. It also provides a rational basis for allocating resources. Taking into account the multiple applications of epidemiological skills in public health, there exists a need to develop epidemiological competencies in health professionals, to help them identify problems, formulate solutions and identify application of such information for public health action.

The major challenge in the World Health Organization (WHO) South-East Asia Region is the inadequate number of professionals and other non-medical health staff who have been trained in epidemiology. ${ }^{5}$ In India, although there have been capacity-building measures for training in epidemiology, the numbers are still insufficient, considering the continuously growing need for skilled epidemiologists in the country. Although this concern has been voiced at several forums, little attempt has been made to analyse the current status of epidemiology training and capacity-building initiatives in the country.

This paper reviews the capacity-building initiatives in epidemiology in India, to aid understanding of the demandsupply gap of epidemiologists and to give future directions for initiating need-based training.

\section{METHODOLOGY}

Data regarding capacity-building initiatives in epidemiology were collected using three strategies. A systematic, predefined approach was used to obtain this information. Each step was conducted in a parallel manner, and the information was entered into an Excel spreadsheet. The first search strategy involved using the information available on the internet. The internet search was conducted using the Google search engine. The first step in this strategy involved identifying a set of key words encompassing various domains related to epidemiology courses. The key words included "epidemiology", "research methods", "field epidemiology training programme" and "epidemiology training". The search was limited to courses offered in India and to collaborations between Indian and foreign institutions, if any. The websites of premier institutions involved in teaching and training of public health, professional organizations and universities were also visited. Detailed information about the courses offered was collected from the respective institutions through their websites and/or by telephone communication.

The second strategy involved a detailed literature review of the epidemiology courses. Indexed and non-indexed journals in the field were identified and searched for notifications and invitation of nominations for educational courses. Key institutes involved in research in epidemiology were identified from the author affiliations. Additional information about short-term training programmes in epidemiology was obtained from this strategy.
The third strategy involved contacting experts in the field of epidemiology in India. This was done by email and/or telephone. They were requested to share information about the courses offered in their institutes and also to suggest the names of other institutes offering courses in the identified fields. This strategy was useful for gathering information on course curriculum, intake capacity of institutions and eligibility criteria.

The search was directed at obtaining data on the following parameters: name and location of the institute offering the course; theme and course duration; course structure; eligibility criteria; and the capacity of training. These parameters were incorporated in a matrix. Data were entered in an Excel spreadsheet with information about the institutions, under the headings (i) institution name and address; (ii) name of course; (iii) duration of course; (iv) intake capacity; (v) year of start of course; (vi) eligibility criteria; and (vi) other comments. After obtaining the list of institutions and their contact details, detailed information about the epidemiology programme, covering the number of sanctioned and filled places, the curriculum, fees, teaching and evaluation systems, was sought from the department/school offering the programme, via email and through telephone follow-up. A structured questionnaire was designed to collect detailed information from the various institutes identified as providing epidemiology courses in India. The questions included information on the type of institute, whether it was government or private, and the year of inception of the course. When information was gathered about a course, the course name was entered in the matrix, and available information about the course and institution was entered through that data source. After that, an attempt was made to verify the data and collect missing data by searching for the email address/telephone number of the institution and contacting them directly.

Any other salient features of relevance to the courses were also incorporated subjectively into this matrix.

To undertake the demand-supply analysis of epidemiologists in the country, first the supply was calculated, based on the output from long-term training programmes in epidemiology. The cumulative output from all training programmes in epidemiology was calculated, to estimate the annual supply of epidemiologists in the country. The demand for epidemiologists was computed by gathering information on the requirement for epidemiologists in epidemiological practice, research and education. For this purpose, an internet search was done to note the requirement and vacancies for epidemiologists in various institutions. The website of the Medical Council of India was browsed to get information on the requirement for epidemiologists in medical colleges. Similarly, the websites of the Ministry of Health and Family Welfare, Indian Council of Medical Research (ICMR) and IDSP were visited, to gather information on the demand for epidemiologists in their offices. Based on the information on long-term training programmes in epidemiology, the demand for faculty in these institutions was calculated. In parallel, information on the demand for epidemiologists was also gathered by contacting experts in the field of epidemiology, to identify programmes/projects where epidemiologists are required. 


\section{RESULTS}

\section{Epidemiology training In India}

Different epidemiology training programmes in India were classified under four broad categories:

1. long-term academic programmes

2. field epidemiology training programmes

3. programmes offered as part of medical and public health education

4. short-term training programmes of less than 6 months' duration.

\section{Long-term academic programmes in epidemiology}

These courses include PhD (Doctor of Philosophy), DNB (Diploma of National Board), MSc (Master of Science), MPhil (Master of Philosophy) and MPH (Master of Public Health), as well as diploma programmes specializing in epidemiology, as summarized in Table 1. Most of the programmes have an eligibility criterion of a graduate degree in medicine or allied sciences, and their duration ranges from 1 to 5 years. Some programmes are only for medical professionals, while others admit students from allied fields. All programmes have classroom teaching as the main teaching method and most of them require research work to be done, leading to the award of a degree/diploma.

\section{Field epidemiology training programmes in India}

The training programmes in field epidemiology in India have a long history. A 3-month field epidemiology training programme was started during 1963-64. ${ }^{6}$ Most short-term field epidemiology training programmes (FETPs) are offered by the National Centre for Disease Control (NCDC), New Delhi. (see Table 2). ${ }^{7}$ In 2001, the National Institute of Epidemiology, Chennai started the 2-year Master of Applied Epidemiology (MAE) programme. This programme was modelled on the Epidemic Intelligence Services (EIS) programme of the United States (US) Centers for Disease Control and Prevention, ${ }^{8}$ and the MAE programme of the Australian National University. ${ }^{9}$ In 2006, NCDC started the 2-year MPH (Field Epidemiology) course. The India EIS was launched in October 2012, and is modelled on the US EIS programme and adapted to Indian conditions. MPH (Field Epidemiology) and MAE are the members of the TEPHINET Training Programmes in Epidemiology and Public Health Interventions Network. ${ }^{10}$

Other capacity-building initiatives include the establishment of networks and alumni associations for epidemiologists. These networks play an invaluable role in sharing of experiences and lessons, advocacy and improving quality of training. Alumni networks are being maintained by most of the institutions offering epidemiology programmes.

\section{Epidemiology training as part of medical and public health education}

\section{Epidemiology training as part of medical education}

Table 3 shows the list of medical programmes that include epidemiology as a part of their curriculum, with details on the number of institutions and annual output of graduates. ${ }^{11-13}$

As a part of undergraduate training, medical graduates are taught the basic principles of epidemiology and biostatistics during the third year of the course. Epidemiology training is an important part of Doctor of Medicine (MD) programmes in community medicine/preventive and social medicine, community health administration and hospital administration, and the skills expected after the completion of this course include application of the principles of epidemiology and biostatistics for public health. During this 3-year training programme, a student is expected to complete at least one research project as a part of their dissertation, which is mandatory for the award of this degree. Other training programmes in these disciplines that incorporate training in epidemiology include the $\mathrm{PhD}$ (Community Medicine) offered by the All India Institute of Medical Sciences.

\section{Epidemiology training as part of public health education}

Traditionally, public health education in India was offered through medical colleges and was open for medical graduates only. However, with the growing recognition of public health as a multidisciplinary subject, there is a conscious shift in public health education in India, with institutions other than medical schools initiating public health education programmes for medical and non-medical graduates. Besides the medical schools, epidemiology is currently a part of $\mathrm{MPH}$, postgraduate programmes in health management, hospital management/ administration, occupational and environmental health programmes and veterinary science courses. The annual intake of these programmes is shown in Table $4 .{ }^{14-17}$

Apart from the four institutes that offer dedicated programmes in epidemiology (see Table 1), the rest of the MPH programmes offer a compulsory module on epidemiology as part of their training in public health. Epidemiology training in these courses includes basic epidemiology with biostatistics, along with practical application of these skills by conducting project work.

\section{Short-term training programmes in epidemiology}

NCDC, formerly the National Institute of Communicable Diseases, New Delhi; the ICMR group of institutes; Public Health Foundation of India; National Institute of Epidemiology (NIE) Chennai; Christian Medical College, Vellore' Post Graduate Institute of Medical Sciences and Research, Chandigarh; National Institute of Health and Family Welfare, New Delhi; Mahatma Gandhi Institute of Medical Sciences, Sevagram; and All India Institute of Hygiene and Public Health, Kolkata are some premier institutes offering shortterm training programmes in epidemiology on a periodic basis. 


\section{Table 1: Long-term academic courses in epidemiology in India}

\begin{tabular}{|c|c|c|c|c|c|}
\hline Institute & Course & $\begin{array}{l}\text { Duration } \\
\text { (years) }\end{array}$ & Type of course & $\begin{array}{l}\text { Enrolment } \\
\text { capacity }\end{array}$ & Eligibility criteria \\
\hline \multicolumn{6}{|l|}{ Doctorate degree (PhD) } \\
\hline $\begin{array}{l}\text { National Institute of Mental } \\
\text { Health and Neurological } \\
\text { Sciences, Bangalore }\end{array}$ & $\begin{array}{l}\text { PhD } \\
\text { (Epidemiology) }\end{array}$ & $2-5$ & $\mathrm{PhD}$ & - & $\begin{array}{l}\text { MD PSM/Community Medicine/ } \\
\text { MSc }\end{array}$ \\
\hline $\begin{array}{l}\text { National Institute of } \\
\text { Epidemiology (ICMR), } \\
\text { Chennai }\end{array}$ & $\begin{array}{l}\text { PhD } \\
\text { (Biostatistics } \\
\text { and } \\
\text { Epidemiology) }\end{array}$ & $2-5$ & $\mathrm{PhD}$ & - & $\mathrm{MD} / \mathrm{MSc}$ \\
\hline $\begin{array}{l}\text { Tata Memorial Hospital, } \\
\text { Mumbai }\end{array}$ & $\begin{array}{l}\mathrm{PhD} \\
\text { (Epidemiology) }\end{array}$ & 5 & PhD & 1 per year & MBBS/Masters in Life Sciences \\
\hline $\begin{array}{l}\text { The Tamil Nadu Dr MGR } \\
\text { University, Chennai }\end{array}$ & $\begin{array}{l}\mathrm{PhD} \\
\text { (Epidemiology) }\end{array}$ & $3-5$ & PhD & 3 so far & $\begin{array}{l}\text { Masters degree in } \\
\text { Epidemiology }\end{array}$ \\
\hline $\begin{array}{l}\text { Achutha Menon Centre for } \\
\text { Health Sciences Studies, } \\
\text { Sree Chitra Tiruanal } \\
\text { Institute for Medical } \\
\text { Sciences and Technology, } \\
\text { Thiruvananthapuram, } \\
\text { Kerala }\end{array}$ & $\begin{array}{l}\text { PhD } \\
\text { (Epidemiology) }\end{array}$ & $3-5$ & PhD & & MBBS with marks of $>60 \%$ \\
\hline \multicolumn{6}{|c|}{ Diplomate of National Board (DNB) } \\
\hline $\begin{array}{l}\text { National Board of } \\
\text { Examinations }\end{array}$ & $\begin{array}{l}\text { DNB ( Field } \\
\text { Epidemiology) }\end{array}$ & - & DNB & - & $\begin{array}{l}\text { MPH (Field Epidemiology) from } \\
\text { NCDC, Delhi; } 2 \text { years' field } \\
\text { experience }\end{array}$ \\
\hline $\begin{array}{l}\text { National Board of } \\
\text { Examinations }\end{array}$ & $\begin{array}{l}\text { DNB } \\
\text { (Epidemiology) }\end{array}$ & - & DNB & - & $\begin{array}{l}\text { MBBS, Previous training and } \\
\text { experience in epidemiology }\end{array}$ \\
\hline \multicolumn{6}{|l|}{ Masters courses } \\
\hline \multicolumn{6}{|c|}{ Master of Science (Epidemiology) } \\
\hline $\begin{array}{l}\text { The Tamil Nadu Dr MGR } \\
\text { University }\end{array}$ & $\begin{array}{l}\text { MSc } \\
\text { Epidemiology }\end{array}$ & 2 & MSc & 4 & $\begin{array}{l}\text { Graduate in health sciences, } \\
\text { any medical related MSc, } \\
\text { MA (Social Work); } 3 \text { years' } \\
\text { experience }\end{array}$ \\
\hline $\begin{array}{l}\text { Christian Medical College, } \\
\text { Vellore }\end{array}$ & $\begin{array}{l}\text { MSc } \\
\text { Epidemiology }\end{array}$ & 2 & MSc & 8 & $\begin{array}{l}\text { Graduate in health sciences, } \\
\text { any medicine-related MSc, MA } \\
\text { (Social Work) }\end{array}$ \\
\hline \multicolumn{6}{|l|}{ Master of Public Health } \\
\hline $\begin{array}{l}\text { All India Institute of } \\
\text { Hygiene and Public Health, } \\
\text { Kolkata }\end{array}$ & $\begin{array}{l}\text { MPH } \\
\text { Epidemiology }\end{array}$ & 2 & $\mathrm{MPH}$ & 20 & Medical graduates \\
\hline $\begin{array}{l}\text { Department of Public } \\
\text { Health, Manipal University, } \\
\text { Manipal, Karnataka }\end{array}$ & $\begin{array}{l}\text { MPH } \\
\text { Epidemiology }\end{array}$ & 2 & $\mathrm{MPH}$ & 18 & $\begin{array}{l}\text { Bachelor's degree in medicine, } \\
\text { dentistry, nursing, allied health, } \\
\text { life science from a recognized } \\
\text { university with a minimum of } \\
60 \% \text { marks in aggregate }\end{array}$ \\
\hline $\begin{array}{l}\text { Tata Institute of Social } \\
\text { Sciences, Mumbai }\end{array}$ & $\begin{array}{l}\text { MPH Social } \\
\text { Epidemiology }\end{array}$ & 2 & $\mathrm{MPH}$ & 20 & $\begin{array}{l}\text { Medical graduates or a } \\
\text { master's degree in any } \\
\text { discipline, or non-medical } \\
\text { graduates with minimum } 2 \\
\text { years' experience in the health } \\
\text { sector after graduation }\end{array}$ \\
\hline $\begin{array}{l}\text { National Institute of } \\
\text { Epidemiology, Chennai }\end{array}$ & $\begin{array}{l}\text { MPH } \\
\text { (Epidemiology } \\
\text { and Health } \\
\text { Systems) }\end{array}$ & $\begin{array}{l}2 \\
\text { (13 months } \\
\text { at NIE, } \\
11 \text { months } \\
\text { in field) }\end{array}$ & Masters & 20 & $\begin{array}{l}\text { MBBS; working in public health, } \\
\text { preferably in state or central } \\
\text { government department/ } \\
\text { medical institutions, age }<45 \\
\text { years }\end{array}$ \\
\hline
\end{tabular}




\begin{tabular}{|c|c|c|c|c|c|}
\hline Institute & Course & $\begin{array}{l}\text { Duration } \\
\text { (years) }\end{array}$ & Type of course & $\begin{array}{l}\text { Enrolment } \\
\text { capacity }\end{array}$ & Eligibility criteria \\
\hline \multicolumn{6}{|l|}{ MPhil (Clinical Epidemiology) } \\
\hline $\begin{array}{l}\text { Clinical Epidemiology } \\
\text { Research Training } \\
\text { Centre, Medical College, } \\
\text { Thiruvananthapuram }\end{array}$ & $\begin{array}{l}\text { MPhil (Clinical } \\
\text { Epidemiology) }\end{array}$ & 2 & Masters & 8 & MD/MS/MDS, age $<45$ years \\
\hline \multicolumn{6}{|l|}{ Postgraduate Diploma } \\
\hline $\begin{array}{l}\text { National Institute of } \\
\text { Epidemiology, Chennai }\end{array}$ & $\begin{array}{l}\text { Postgraduate } \\
\text { Diploma in HIV } \\
\text { Epidemiology }\end{array}$ & 2 & $\begin{array}{l}\text { Postgraduate } \\
\text { diploma }\end{array}$ & 5 & $\begin{array}{l}\text { MBBS degree, current position } \\
\text { in central/state government, } \\
\text { preferably in HIVIAIDS control } \\
\text { programme; minimum } 2 \text { years' } \\
\text { experience in public health/HIV } \\
\text { surveillance or programme- } \\
\text { related activities; age } 40 \text { years } \\
\text { or less; last advertised in } 2012\end{array}$ \\
\hline $\begin{array}{l}\text { Diploma in Epidemiology } \\
\text { (in-service programme } \\
\text { under IDSP) }\end{array}$ & $\begin{array}{l}\text { Public Health } \\
\text { Foundation } \\
\text { of India and } \\
\text { National } \\
\text { Health System } \\
\text { Resource } \\
\text { Centre }\end{array}$ & 18 months & $\begin{array}{l}\text { Postgraduate } \\
\text { diploma }\end{array}$ & - & $\begin{array}{l}\text { Epidemiologists working under } \\
\text { IDSP }\end{array}$ \\
\hline
\end{tabular}

ICMR: Indian Council of Medical Research Master of Public Health; IDSP: Integrated Disease Surveillance Project; MA: Master of Arts; MBBS: Bachelor of Medicine, Bachelor of Surgery; MD: Doctor of Medicine; MS: Master of Surgery; MDS: Master of Science in Dentistry; MSc: Master of Science; MPhil: Master of Philosophy; NIE: National Institute of Epidemiology; PhD: Doctor of Philosophy;

PSM: preventive and social medicine; UGC: University Grants Commission. 


\begin{tabular}{|c|c|c|c|}
\hline Course name & Institution & Duration & Participants \\
\hline $\begin{array}{l}\text { Training programme on basic } \\
\text { epidemiology, outbreak surveillance and } \\
\text { response }\end{array}$ & NCDC, New Delhi & 10 days & Paramedical staff \\
\hline IDSP FETP & Various Institutes & 2 weeks & District surveillance officers \\
\hline $\begin{array}{l}\text { Training on prevention and control of } \\
\text { communicable diseases }\end{array}$ & NCDC, New Delhi & 1 month & $\begin{array}{l}\text { Paramedical staff from the WHO South-East } \\
\text { Asia Region }\end{array}$ \\
\hline Regional FETP & NCDC, New Delhi & 3 month & $\begin{array}{l}\text { Senior and mid-level health professionals } \\
\text { from the WHO South-East Asia Region }\end{array}$ \\
\hline Masters in Applied Epidemiology & NIE, Chennai & 2 years & In-service health professionals \\
\hline MPH (Field Epidemiology) & NCDC, New Delhi & 2 years & MBBS, working in public health \\
\hline EIS training programme & NCDC, New Delhi & 2 years & $\begin{array}{l}\text { MBBS and MD (Community Medicine) or } \\
\text { MD (paraclinical) with } 2 \text { years' experience }\end{array}$ \\
\hline
\end{tabular}

EIS: India Epidemic Intelligence Service; FETP: field epidemiology training programme; IDSP: Integrated Disease Surveillance Project; MBBS: Bachelor of Medicine, Bachelor of Surgery; MD: Doctor of Medicine; MPH: Master of Public Health; NCDC: National Centre for Disease Control; NIE: National Institute of Epidemiology; WHO: World Health Organization.

\begin{tabular}{|c|c|c|}
\hline Course & Number of institutions & Annual intake capacity \\
\hline MBBS & 412 & 52325 \\
\hline MD (Community Medicine/Preventive and Social Medicine) & 229 & 802 \\
\hline Diploma in Public Health & 39 & 90 \\
\hline Diploma in Community Medicine & 6 & 11 \\
\hline MD (Hospital Administration) & 8 & 31 \\
\hline MD (Community Health Administration) & 1 & 10 \\
\hline Masters in Hospital Administration & 2 & 24 \\
\hline Diploma (Health Administration) & 1 & 6 \\
\hline Diploma (Hospital Administration), & 1 & 6 \\
\hline
\end{tabular}

MBBS: Bachelor of Medicine, Bachelor of Surgery; MD: Doctor of Medicine.

\begin{tabular}{lc} 
Table 4: Public health programmes offering epidemiology training, with annual intake capacity \\
\hline Academic stream & Annual intake/year \\
Health management & 2500 \\
Hospital management and administration & 2473 \\
Masters in Public Health & 623 \\
Occupational and environmental health & 460 \\
Veterinary sciences & 1500 \\
\hline
\end{tabular}

The duration of these courses varies from 5 days to 6 months. Some short-term training programmes also incorporate training in specific statistical software packages. The Industrial Toxicology Research Centre, Lucknow, offers training in the subspecialty of environmental epidemiology, while the National Institute of Mental Health and Neurosciences, Bangalore, conducts training in neuropsychiatric epidemiology.

\section{Other capacity-building measures}

\section{The role of professional organizations in} capacity-building in epidemiology

Several professional organizations in the country, including the Indian Association of Preventive and Social Medicine, Indian Public Health Association, Indian Association of Epidemiologists, Indian Society of Medical Statisticians and Indian Association of Occupational Health, have played a 
pivotal role in building the capacity of health professionals in epidemiology in India, and strive to continue in this endeavour. These organizations are conducting short-term training programmes and workshops on research methodology and epidemiology, through their national branch and state chapters.

\section{The role of the World Health Organization}

Realizing the limited capacity of the health staff in India in field epidemiology, WHO has been providing technical assistance to the national institutions involved in field epidemiology training. Two such courses supported by WHO are the 3-month FETP at NCDC and the 2-year MAE-FETP at NIE. Other than this, WHO supports various short-course training programmes.

In its roadmap to combat infectious diseases, the WHO Regional Office for South-East Asia developed a strategy that is consistent with the WHO International Health Regulations (2005), ${ }^{18}$ which underlines the need for strengthening national capacity for surveillance, risk assessment, preparedness and response. Based on the roadmap and its strategy, WHO is working with Member States and other stakeholders to strengthen epidemiological capacity by promoting and strengthening the 2-year field epidemiology training programme and also short-term training (for 2, 4 and 13 weeks) in epidemiology, surveillance and prevention and control of communicable disease. ${ }^{19}$

To promote the application of epidemiology, both within WHO and in Member States, to programmes for disease prevention and control, an informal working group on epidemiology has been established in the WHO Regional Office for South-East Asia. ${ }^{20}$ The mapping of epidemiology and related training capacity has also been undertaken as one of its activities to develop an overview of current capacity in epidemiology and related training programmes in the region.

\section{The IndiaCLEN initiative}

IndiaCLEN, one of the seven regional networks of the International Clinical Epidemiology Network (INCLEN), is a non-profit health-research network registered with the registrar of societies at Trivandrum, Kerala, since 1991. Beginning with a membership of 45, INCLEN has trained fellows in clinical epidemiology, health economics, biostatistics and health social sciences; IndiaCLEN currently has about 350 members across 135 medical institutions. To support the dissemination and application of clinical epidemiological principles in the education/research activities, IndiaCLEN has supported the establishment of clinical epidemiological units in 11 medical colleges. Apart from this, it has also supported the establishment of the Clinical Epidemiology Resource and Training Centre, Trivandrum, which offers an MPhil programme in clinical epidemiology. ${ }^{21}$

\section{Institutional capacity-building initiatives}

Another landmark in institutional capacity-building initiatives is the establishment of NIE at Chennai, with the broad objectives of development of human resources in epidemiology and biostatistics and networking of the various institutes at the national level for epidemiological purposes. The institute has the distinction of being the WHO Collaborating Centre for Epidemiology of Leprosy and has been identified as a technical resource group for epidemiology of HIV by the National AIDS Control Organization. At present, it is one of the premier institutes for epidemiology training in India, with an area of field practice covering a well-characterized population of 500000.22

\section{Demand-supply analysis}

A supply analysis for epidemiology training was done through estimating the output of training programmes in epidemiology. The annual enrolment capacities of long-term academic programmes in epidemiology range from 1 to 20 per cohort. The potential training capacity per annum through the 19 long-term training programmes in epidemiology and three long-term FETPs is approximately 192 candidates per year. In addition, about 980 candidates complete their MD/Doctor of Public Health (DPH)/Doctor of Community Medicine (DCM) tenure every year, with a substantial part of their training time dedicated to epidemiology. As a result, approximately 1172 trained epidemiologists are added to the pool of epidemiologists each year. However, owing to more lucrative opportunities and the availability of jobs in other fields, eventually very few candidates with postgraduate degrees in preventive and social medicine/community medicine are available for jobs as epidemiologists.

There is dire need for epidemiologists in the country. As per the norms of the Medical Council of India, every medical college must have one epidemiologist under the Department of Preventive and Social Medicine/Community Medicine. With 412 medical colleges, this amounts to a demand for 412 epidemiologists by medical colleges alone.

Epidemiologists are also required as faculty for training programmes in this discipline. To serve the 19 long-term programmes in epidemiology and three long-term FETPs, 65 faculty members trained in epidemiology are required to serve these institutes, taking into account a faculty:student ratio of 1:1 for doctoral and 1:4 for masters' programmes. At least 135 additional faculty members are required to teach epidemiology in 135 institutes offering health management, hospital administration, public health and occupational health programmes, which include epidemiology as a part of their curricula.

Under the IDSP, the state surveillance team needs one epidemiologist at the state headquarters, amounting to 35 consultants and one epidemiologist for 676 districts. Besides this, trained epidemiologists are also needed for 26 permanent institutes under ICMR and national health programmes, as well as international organizations, bilateral organizations and NGOs in the health sector. The total estimated demand including all these sectors is for at least 3289 trained epidemiologists. 


\section{DISCUSSION}

Capacity-building is much more than training and involves human-resource development and institutional and programme development conducive to the generation of appropriate responses to emerging needs. ${ }^{23}$ Capacity-building in epidemiology was identified as an important and urgent issue during the South-East Asia Regional Conference on Epidemiology, New Delhi (March 2010), organized by WHO with several national and international partners. ${ }^{24}$

Using a systematic approach, this study collected information about capacity-building initiatives in epidemiology and conducted a demand-supply situation assessment of epidemiologists in India. In the absence of an official database of epidemiologists in the country, the study used a search strategy employing tools like internet search, scanning information through peer-reviewed journals and contacting institutions and experts through email/telephone communication. Despite making efforts to collate data from as many sources as possible, there is a likelihood of missing out information that may not be captured by these data sources and this is one of the limitations of the study. Another limitation is that, in the demand-supply analysis of epidemiologists, the overall supply and demand of epidemiologists was calculated, irrespective of their training level or specialty. Epidemiologists trained outside the medicalcollege system may not be eligible for epidemiology teaching positions in government-run medical colleges. Similarly, those trained in one subspecialty of epidemiology may not be suitable for roles in other subspecialties. For a more accurate analysis, role-specific demand-supply analysis should be done, which is beyond the scope of this study. Another area that could be explored is an assessment of the manpower status of epidemiologists at various institutes. This would provide further information on the current scenario and identify the fields/institutes in which the demand-supply gap is largest.

In India, training in epidemiology is being delivered as part of many courses, as well as through dedicated programmes in epidemiology. The results of this study show that, despite the large population of the country, the enrolment capacity in most programmes still remains low, and in some cases even the available places are not always filled. In contrast to 19 longterm training programmes in epidemiology in India, the United States of America (USA), with one seventh of the population of India, has 402 masters' programmes in epidemiology. This is exclusive of 96 doctoral programmes in epidemiology and its subspecialties offered by various universities across USA..$^{25}$ With an increasing population in India, the need for trained epidemiologists is likely to increase. However, the limited numbers of trained professionals in epidemiology are going to be a restraint to catering for the increasing demand of training with time. Distance-learning courses have recently been launched and can probably cater for a larger audience with limited resources. In distance-learning mode, apart from the courses offered by Indian institutes, on which the present study focuses, international institutes can also contribute to capacitybuilding of professionals in India. This includes provision of long-term programmes and short courses, available either by enrolling in foreign universities or accessing opensource training materials like MOOCs (massive open online
courses).Though long-term academic programmes by foreign universities may not be affordable for all, because of high fees, the open-source platforms like MOOCs offer immense potential for capacity-building of epidemiologists, especially in subspecialties where there is lack of expertise in institutions across the country.

The results of this study show that courses are offered in the subspecialties of applied epidemiology, field epidemiology, social epidemiology and clinical epidemiology. The most frequently taught subspecialty is field epidemiology, with NCDC, Delhi, and NIE, Chennai, offering long-term courses in this subspecialty. Other specialties are taught only in selected institutes. At present, there are no courses focusing on environmental epidemiology, molecular epidemiology, seroepidemiology, occupational health epidemiology, and other subspecialties, thus providing abundant scope to expand the horizons of training in epidemiology by providing courses in these disciplines that are still unexplored.

The boundaries of epidemiology are shifting. The past decades ushered in unprecedented technological growth that led to innovations in communications and computation. Each of these elements has its place in epidemiology training and that can revolutionize and revitalize the teaching and practice of epidemiology. Training programmes in epidemiology can also make use of emerging newer technologies, such as for training in computation and the use of newer methods of communication for surveillance activities. Distance-learning courses can also be made interactive and user friendly, with the use of developments in telecommunication and various e-learning platforms.

Apart from increasing the output of programmes in terms of enrolment capacity and number of courses, which will require a lot of resources to cover and subsequently implement, concerted efforts should be directed towards improving the output of existing courses. As large numbers of skilled epidemiologists are a product of $\mathrm{MD} /$ diploma courses in community medicine/ preventive and social medicine, revision of the curriculum for teaching epidemiology in these courses, to provide appropriate competencies to the students, would be one step closer towards achieving the larger goal and objectives.

Building institutional capacity is a crucial capacity-building measure, along with building human-resource capacity. Both are closely interrelated and complement each other. At present, few organizations are taking initiatives in this regard. However, this requires more attention, as capacity-building of the institutions need to be addressed at a long-term, strategic level and with panoramic thinking. This would also provide sustainability to the programmes and have a far-reaching impact.

Another issue that demands attention is the accreditation of courses in epidemiology, which can serve as step towards quality improvement in epidemiology training across the country. At present, although there are courses available for specialized training in epidemiology, they are imparted under different umbrellas and it is difficult to monitor their quality on a common platform. Courses offered in medical colleges are accredited by the Medical Council of India. Courses taught 
outside the medical colleges are regulated by the university they are affiliated to, or the institutions where they are taught. At present, there is no separate body for accreditation of epidemiology or public health courses. ${ }^{26}$ The possibility of establishing national accreditation standards can be explored in the near future, to further improve the expected outputs of training programmes offered.

In view of the large population of India, the supply of trained personnel in epidemiology is far from sufficient for the evergrowing demand for specialists in this field. This wide gap between supply and demand needs urgent attention. To fill this gap, there is a need to increase the number of training programmes, which in turn requires institutional strengthening and collaboration. For optimal use of expertise, there is a need to maintain an updated database of graduates in epidemiology and related training disciplines, and to establish functional networking of training programmes and alumni. Other initiatives that can improve the delivery of existing programmes are continuous quality-improvement procedures for curricula. Complementarities and integration of capacity-building initiatives themselves are of crucial importance. Without an adequate epidemiology workforce, public health cannot take off - and without public health programmes, disease prevention and health promotion will remain stunted. In short, planning for "human resources for health" without an overall strategy for epidemiology and epidemiologists is self-defeating. ${ }^{27}$

\section{REFERENCES}

1. Murray CJL, AD Lopez, editors. The global burden of disease: a comprehensive assessment of mortality and disability from diseases, injuries, and risk factors in 1990 and projected to 2020. Boston: Harvard School of Public Health; 1996.

2. Gubler DJ. Emerging and re-emerging vector borne diseases in India. In: Proceedings of the South-East Asia Regional Conference on Epidemiology, New Delhi, 8-10 May 2010. New Delhi: World Health Organization Regional Office for South-East Asia; 2010:43-8 (http:// apps.searo.who.int/PDS_DOCS/B4665.pdf, accessed 1 December 2015).

3. Epidemiology and related training capacity in selected countries of South East Asian Region: a rapid review. New Delhi: World Health Organization Regional Office for South-East Asia; 2009:1-3 (SEAEPID-130; http://apps.searo.who.int/PDS_DOCS/B4257.pdf, accessed 1 December 2015).

4. Coker RJ, Hunter BM, Rudge JW, Liverani M, Hanvoravongchai P. Emerging infectious diseases in southeast Asia: regional challenges to control. Lancet. 2011;77(9765):599-609. doi:10.1016/S01406736(10)62004-1.

5. Dhillon PK, Jeemon P, Arora NK, Mathur P, Maskey M, Sukirna RD et al. Status of epidemiology in the WHO South-East Asia region: burden of disease, determinants of health and epidemiological research, workforce and training capacity. Int J Epidemiol. 2012;41:847-60. doi:10.1093/ije/dys046.

6. Dhariwal A, Jain SK. FETP in India: ten years of experience. In: Proceedings of the South-East Asia Regional Conference on Epidemiology, New Delhi, 8-10 May 2010. New Delhi: World Health Organization Regional Office for South-East Asia; 2010:285-8 (http:// apps.searo.who.int/PDS_DOCS/B4665.pdf, accessed 1 December 2015).

7. National Centre for Disease Control (http://www.ncdc.gov.in/index1. asp?linkid=233, accessed 1 December 2015).

8. Thacker SB, Dannerberg AL, Hamilton DH. Epidemic Intelligence Service of the Centre for Disease Control and Prevention: 50 years of training and service in applied epidemiology. Am J Epidemiol. 2001;154:985-92.
9. Patel MS, Philips CB. Strengthening field based training in low and middle income countries to build public health capacity: lessons from Australia's Master of Applied Epidemiology program. Aust New Zealand Health Policy. 2009;6:5. doi:10.1186/1743-8462-6-5.

10. TEPHINET. Training Programs in Epidemiology and Public Health Interventions network ( (www.tephinet.org, accessed 1 December 2015).

11. MedicalCouncil ofIndia.List of colleges teaching MBBS(http://mciindia. org/InformationDesk/ForStudents/ListofCollegesTeachingMBBS.aspx, accessed 1 December 2015).

12. National Board of Examinations (http://www.natboard.edu.in/matter. php?notice_id=291, accessed 1 December 2015).

13. Medical Council of India. List of colleges teaching PG courses (http://mciindia.org/InformationDesk/ForStudents/ ListofCollegesTeachingPGCourses.aspx, accessed 1 December 2015).

14. Sharma K, Zodpey S. Need and opportunities for health management education in India. Indian J Public Health. 2010;54:84-91. doi:10.4103/0019-557X.73276.

15. Sharma K, Zodpey SP. Health and hospital management education in India. Healthline (The Journal of Indian Association of Preventive and Social Medicine, Gujarat Chapter) 2011;2(1):13-16.

16. Zodpey SP, Negandhi H, Tiwari RR. Mapping 'Occupational Health' courses in India: a systematic review. Indian J Occup Environ Med. 2009 Dec;13(3):135-40. doi:10.4103/0019-5278.58917.

17. Veterinary Council of India. List of veterinary colleges ( http://www. vci.nic.in/forms/list.aspx?lid=803\&Id=24, accessed 1 December 2015).

18. International Health Regulations (2005), 2nd ed. Geneva: World Health Organization; 2008 (http://www.who.int/ihr/9789241596664/en/, accessed 1 December 2015).

19. Combating emerging infectious diseases in the South-East Asia Region. New Delhi: World Health Organization Regional Office for South-East Asia; 2005 (SEA-CD-139; http://www.searo.who.int/entity/emerging diseases/documents/b0005.pdf, accessed 1 December 2015).

20. Note for the Record. Meeting of the Informal Working Group on Epidemiology, June 2008.

21. IndiaCLEN. Indian Clinical Epidemiology Network (http://indiaclen. org/, accessed 1 December 2015).

22. National Institute of Epidemiology (http//:www.nie.gov.in, accessed 1 December 2015).

23. United Nations Economic and Social Council. Committee of Experts on Public Administration, Fifth Session, New York 27-31 March 2006. Agenda item 5. Definition of basic concepts and terminologies in governance and public administration. New York: United Nations; 2006 (E/C.16/2006/4; http://unpan1.un.org/intradoc/groups/public/ documents/un/unpan022332.pdf, accessed 1 December 2015).

24. Executive Summary. In: Proceedings of the South-East Asia Regional Conference on Epidemiology, New Delhi, 8-10 May 2010. New Delhi: World Health Organization Regional Office for South-East Asia; 2010:11-14 ((http://apps.searo.who.int/PDS_DOCS/B4665.pdf, accessed 1 December 2015).

25. Association of Schools of Public Health (http://www.aspph.org/ program-finder, accessed 1 December 2015).

26. Sharma K, Zodpey S, Zahiruddin QS. Accreditation of public health education in India: enhancing quality, competence and trust. Natl Med J India. 2013;26(6):344-7.

27. Nachega JB, Uthman OA, Yuh-Shan Ho, Lo M, Anude C, Kayembe P et al. Current status and future prospects of epidemiology and public health training and research in the WHO African region. Int J Epidemiol. 2012;41(6):1829-46. doi:10.1093/ije/dys189.

How to cite this article: Zodpey S, Pandey A, Murhekar $M$, Sharma A. Landscaping capacity-building initiatives in epidemiology in India: bridging the demand-supply gap. WHO South-East Asia J Public Health 2015;4(2): 204-212.

Source of Support: Nil. Conflict of Interest: None declared. Contributorship: All authors contributed equally to the design of the study; development of the methodology; data collection and analysis; and drafting and revision of the manuscript. 